\title{
Inequalities and Justice
}




\title{
Access to Communication Tools in Stalin's Soviet Union*
}

\author{
Larissa Zakharova
}

In Vasily Grossman's Life and Fate, the physicist Victor Pavlovich Strum is returning to Moscow after being evacuated to Kazan during World War II and worries that the telephone in his apartment may no longer be working. He asks himself whether evacuees "thought about trivia like this a hundred years ago on their way back to Moscow after the defeat of Napoleon." ${ }^{1} \mathrm{He}$ fears it may be inappropriate to be concerned with his own comfort and the advantages of access to communication networks at a time when the country and its capital city are suffering from war and deprivation. His wife is equally obsessed with the telephone. As soon as she walks through the door, she lifts the receiver, blows into it, and announces to her husband: "Well, the telephone seems to be working all right."2 For this family of the scientific elite, the telephone represents a certain return to normality. At the same time, their surprise that the line is functioning properly says something about representations of the telephone service's quality: defectiveness and malfunction were part of daily life. ${ }^{3}$

This article was translated from the French by Michael C. Behrent.

* I would like to thank Grégory Dufaud, Catherine Gousseff, Aleksandra MajstoracKobiljski, Nathalie Moine, and Sophie Tournon for carefully reading this article and for their invaluable advice.

1. Vasily Grossman, Life and Fate, trans. Robert Chandler (New York: New York Review of Books Classics, 2006), 445.

2. Ibid.

3. On malfunctions in Soviet bureaucratic documents and the ways historians can deal with them, see Grégory Dufaud, "Que faire des dysfonctionnements? Quelques obser- 
The suggestive ambiguity of this anecdote sheds light on the central question of this article, which demonstrates how the tools of interpersonal communication-notably the mail, the telegraph, and the telephone-structured Soviet geography and society under Stalin. While Soviet propaganda and information technology have often been studied, the role of long-distance communication has yet to be seriously examined. ${ }^{4}$ Still, an evaluation of mail and telephone access sheds light on spatial hierarchies, opportunities for long-distance sociability, and, consequently, the social model that Soviet authorities were seeking to establish. Collectivism, a characteristic often associated with Soviet society, is inseparable from public interaction. Within this context, the place of interpersonal exchange through communications technology is far from self-evident: not being truly collective, this type of interaction may arouse suspicion in a regime wary of critical opinion. ${ }^{5}$ Intensified interaction between individuals can complicate control mechanisms (such as mail censorship and wiretaps), since it requires the mobilization of increasing human and technical resources. Moreover, different forms of interaction require different forms of control. The political police had some control over the flow of postal communication: they could delay letter delivery and thus temporarily interrupt an exchange. However, they had no way to impact telephone communication, which allowed for simultaneous, recurring, and potentially more subversive interaction.

The Bolsheviks thus faced a dilemma: should they extend communication networks or tighten their grip on the population? A tension emerged between the two roles of communication tools: the social and the political. ${ }^{6}$ On the one hand, Soviet leaders needed the mail, the telegraph, and the telephone for such governmental reasons as transmitting orders and the political education of the population.

vations sur l'écriture de l'histoire de l'Union soviétique," A contrario 1, no. 17 (2012): 53-69.

4. Jennifer Turpin, Reinventing the Soviet Self: Media and Social Change in the Former Soviet Union (Westport: Praeger, 1995); Jeffrey Brooks, Thank You, Comrade Stalin! Soviet Public Culture from Revolution to Cold War (Princeton: Princeton University Press, 2000); Tat'iana Goriaeva, Radio Rossii. Politicheskii kontrol' sovetskogo radioveshchaniia v 19201930-kh godakh (Moscow: Rosspèn, 2000); Goriaeva, "Velikaia kniga dnia...” Radio v SSSR (Moscow: Rosspèn, 2007); Thomas C. Wolfe, Governing Soviet Journalism: The Press and the Socialist Person after Stalin (Bloomington: Indiana University Press, 2005); Alexandre Sumpf, Bolcheviks en campagne. Paysans et éducation politique dans la Russie des années 1920 (Paris: GNRS Éditions, 2010); and Kristin Roth-Ey, Moscow Prime Time: How the Soviet Union Built the Media Empire that Lost the Cultural Cold War (Ithaca: Cornell University Press, 2011).

5. On long-distance interpersonal communications as spaces in which critical opinion takes shape, see Malte Griesse, Communiquer, juger et agir sous Staline. La personne prise entre ses liens avec les proches et son rapport au système politico-idéologique (Frankfurt: Peter Lang, 2011).

6. On the competition between political and social uses of communication tools during the early Soviet years, see Larissa Zakharova, "'Le socialisme sans poste, télégraphe et machine est un mot vide de sens.' Les bolcheviks en quête d'outils de communication (1917-1923)," Reoue historique 660, no. 4 (2011): 853-73. 
For example, in 1924, the Thirteenth Congress of the Russian Communist Party requested the distribution of "two million newspapers in villages, or at least one newspaper for every ten peasant households." 7 The postal service thus became the primary vehicle for disseminating official discourse to hundreds of thousands of villages strewn across Soviet territory.

The organization of the postal and telephone networks reflected a will to control the peripheries of a vast territory spanning two continents. At the end of the Civil War, consolidating power meant centralization. The first goal was to connect the capital and provincial centers through communication channels based on a radial pattern. By Stalin's time, an interlocking network that would connect each region was still not on the agenda, for both political reasons and the lack of technical resources. ${ }^{8}$ To control the periphery, more communication tools were undoubtedly necessary. However, extended communication lines and greater access to communication tools-particularly the telephone, which leaves no written trace-risked making local leaders more independent and autonomous. Consequently, telecommunication lines had to be distributed in a way that allowed peripheral regions to be controlled efficiently while simultaneously discouraging any desire for independence.

On the other hand, the development of a postal network meant an increase in interpersonal long-distance communication and thus a contraction of space and time. This was explicitly stipulated by a 1933 order on "The Foundations for Rebuilding the Postal Economy (pochtovoe khoziaistvo) in the USSR." 9 The order acknowledged the public demand for communication, particularly private communication. This modernizing project suggested that communication was not only functional, but also relational, arising from a need for interpersonal sociability. The result of this connection between control and communication was that individual opportunities for long-distance communication were shaped by social hierarchies. While the state that emerged out of the October Revolution aspired to build an egalitarian society, in practice it developed a systematic policy of social discrimination, justified on the grounds of class struggle and participation in "socially useful" work. ${ }^{10}$ The tension between an egalitarian ideal and the creation of privileges lay at the heart of Soviet communications policies. In the postal sector, leaders quickly adopted a system of preferential rates for the social groups in whose name the revolution had been made. Due to its scarcity, however, new technology was not widely

7. Collection (fond, henceforth "f.") 3527, inventory (opis', henceforth "op." or "per.") 4, file (delo, henceforth "d.") 116, page (list, henceforth "l.") 4, Russian State Archives of the Economy (Rossiiskii Gosudarstvennyi Arkhiv Ekonomiki, hereafter "RGAE"), Moscow.

8. In this respect, the Stalinist regime did not greatly differ from European countries, which-like France when it nationalized its postal service-modeled their networks on their administrative and political structures. Catherine Bertho, ed., Histoire des télécommunications en France (Toulouse: Érès, 1984), 63-64.

9. F. 3527, op. 4, d. 722, 1. 1, RGAE, Moscow.

10. On this basis, exemplary workers-the Stakhanovites-were entitled to a higher standard of living. 
distributed until after the Stalinist era. A dearth of technical resources meant that access to telephones was reserved for the elite. As a result, the telephone quickly became a mark of social prestige.

Depending on the territorial level under consideration, social and spatial hierarchies either contradicted or complemented one another. If one considers the USSR as a whole, elites from remote regions faced discrimination in their access to modern communication tools because of prevailing spatial hierarchies. In cities like Moscow, there was a tendency toward segregation: authorities preferred to house members of the elite in neighborhoods that were connected to telephone networks. In urban areas, one observes a conscious political choice to link social and spatial hierarchies, thus "spatializing" privileges. Tensions between these hierarchies, as well as between the desire to create a society founded on communication and efforts to stall the development of conditions permitting a social dynamic based on open communication, were the ultimate reasons for many customer complaints. By launching the "self-criticism" campaign in 1928, the Stalinist regime established a means by which people could challenge social and spatial hierarchies. The state encouraged citizens to denounce and complain about the system's flaws, maintaining that criticism "from below" would help the country to advance along the path to Socialism and create a society of equals. The institutionalization of complaint procedures represented an effort to establish a political culture founded on customers' collective rights and standard procedures guaranteed by a mediating state. These procedures allowed for a system of "two-way surveillance." Individuals participated in the supervised oversight of public services, thus providing the regime with information on what citizens were thinking. ${ }^{11}$ Customers had the impression that they had the right to challenge government policies, notably in the realm of communications. By registering their complaints concerning the failures of communication services and their difficulties in accessing them (for instance, acquiring a home telephone line), customers articulated their vision of social justice and, more generally, of what Socialism should mean for daily life. Though these procedures were not particularly efficient, the flaws that were revealed offset the privileges inherent in social status and spatial position.

This essay seeks to weave the story of the development of communication networks into the chronology of Soviet political and social history. Until the early 1930s, telephones were a marginal phenomenon. Their scarcity explains why communications policies were primarily aimed at the postal and telegraphic networks. It was not until 1932 that the Commissariat for Posts and Telegraphs became the Commissariat of Communications, thus acknowledging the importance of the telephone network. Because they bypassed the countryside, telephones contributed to the compartmentalization of space and thus of urban society. They exacerbated 
inequalities between town and village as well as within cities themselves. My analysis will gradually shift from a consideration of the postal to the telephone system. It will equally take into account the different levels at which the communications system operated: by examining both the macro and the micro level in addition to the nation as a whole and individual cities, it will be possible to understand how social and spatial hierarchies both clashed and converged. ${ }^{12}$

Ultimately, this article will demonstrate how the postal service evolved from an instrument of mass support into a communications service that served as a tool for social and territorial ordering. World War II had important consequences for the social and spatial hierarchies that arose from communications access, which was established during the interwar period but was disrupted by destruction, evacuation, and the transfer of communication networks from West to East. Postwar policies tended to restore the network's radial configuration, which emulated the country's administrative divisions, thus restoring discrimination in communications access, notably for laborers on large worksites. An examination of the social reception of these policies through complaints and customers' opinions will reveal the regime's limited success in imposing a hierarchical system.

\section{Building a New Society}

The events of October 1917 depended on effective action and, to a large extent, on the quality of the communications systems through which revolutionary action was coordinated: while preparing his coup d'état, Lenin ordered the cutting of the telephone lines at the Winter Palace in Petrograd, where the Provisional Government was located, and the occupation of the central telegraph and telephone offices. With the subsequent territorial conquests during the Civil War, telegraphs, telephone lines, and post offices were reclaimed, making it possible to measure the network's potential and evaluate society's communication needs. Bolshevik leaders clearly saw that communication was central to building a Socialist society and reconfiguring social relations.

The measures taken relating to postal, telephone, and telegraph services mirror the regime's political evolution. The period of War Communism (1917-1921) was characterized by a desire to create a society in which the postal service would be the primary conduit for long-distance communication, while the telephone and telegraph would be reserved for administrative use. The New Economic Policy (NEP) brought this policy to an end, inaugurating a system of privilege and favoritism in communications access aimed at promoting long-distance exchange for Red Army soldiers and their families as well as workers and employees of Soviet institutions. This system also restricted access to communication for "class enemies."

12. Changes in scale also obey a logic that is specific to technological change (a fact that is not particular to the USSR): while the advantage of the telegraph was to allow longdistance communication, the telephone first developed within cities. Bertho, Histoire des télécommunications, 52. 
Rural areas and low-density regions that were far from the center found themselves excluded for a variety of reasons: inadequate lines and services, meager family resources, and high illiteracy rates. The 1928 Socialist offensive made unequal access to communication tools a lasting problem, even as demand perceptibly grew. Projects for developing communication networks primarily sought to offer telephone and telegraph access to postal service users, further reinforcing the exclusion of regions and communities in which social relations remained narrow and local. Within the spatial hierarchy, Moscow ranked first in concentration of telephone equipment and connected telophone lines.

\section{From Free Mail to a System of Privileges}

The Bolsheviks' desire for a communications system organized along radial lines was formulated even before they had a clear sense of their situation and available resources. Political decisions relating to the institutionalization of communications services evolved in conjunction with the development of technical resources. On April 16, 1918, Vadim Podbelskii, the post and telegraph commissar, and Lenin, the government chairman, adopted a decree on the "Organization of the Management of Postal and Telegraphic Institutions in the Soviet Republic," which called for centralization in order to improve their efficiency, notably through commissars appointed to run some fifty postal and telegraphic units (pochtovo-telegrafnyi okrug). During the summer of 1918, these units were abolished, and the executive committees of provincial Soviets opened communications departments in their place. Every agency located on a province's territory was placed under the authority of its provincial communications department. ${ }^{13}$ From the beginning, communications services were thus tightly integrated into the state's administrative structure.

Though they were eager to establish a centralized communications system, the Bolsheviks nonetheless faced shortages and even, in some regions, a complete absence of communications infrastructure. Indeed, the abolition of the zemstros, institutions of local self-government, led to the disappearance of the communication services with which they provided their provinces. Lacking transportation, many rural postal agencies shut down. The Civil War prevented the implementation of a coherent policy. Other post offices were shut down by the owners of the buildings in which they operated. The number of agencies declined by more than half between 1916 to 1919, falling from 14,000 to 6,000. In 1919, the Commissariat for Posts and Telegraphs investigated the network. In response to its request for information on the condition and extent of postal routes, it received many telegrams explaining that some routes no longer existed, as was the case in Gomel, Tula, Vitebsk, Yaroslavl, and Moscow provinces. In 1919, the length of postal routes in kilometers was one third of what it had been in $1916 .^{14}$ 
In the midst of the Civil War, the Bolsheviks sought the public's approval. The repression associated with the Red Terror was accompanied by populist measures. Despite the postal system's state of disrepair, the Bolsheviks announced that letters weighing less than fifteen grams would be delivered free of charge beginning on January 1, 1919. This invitation to engage in long-distance communication was seen as a way of incurring the public's political loyalty and avoiding discontent within the armed forces. Letter-writing between soldiers and their loved ones was seen as a way to guarantee order.

Proletarians of the city, the front, and the village, take full advantage of the rights you have conquered since the October Revolution! Fervently share your revolutionary ideas with the city, the front, and the countryside! Correspondence strengthens the unity of proletarians of the city, the front, and the village poor, and helps to organize Russia's revolutionary and Socialist forces! $!^{15}$

To implement this measure, leaders had to find ways to ensure mail delivery despite the war and disruption of communication networks. The center tried to interest regions in distributing mail at the local level. The principle of exchanging services led to a system of privileges. In addition to opening new postal and telegraphic offices, postal commissioners were appointed to deliver mail and money transfers to villages lacking postal service and to collect and drop their letters off at neighboring post offices. In this way, the weak density of the network led authorities to adopt an individualized approach that could be undermined by the mass use of communication tools. Recognizing that its network needed to expand, the postal service aspired to be locally oriented. Commissioners were expected to travel by foot or possibly on horseback. ${ }^{16}$ Horses could belong to post offices. Between 1919-1920, it was also possible to "enter into mail delivery contracts with artels and individual agents." ${ }^{17}$ Subsequently, in 1924, the Commissariat for Posts and Telegraphs reached an agreement with the executive committees of local Soviets, whereby the latter would make transportation (generally horses) available to post offices in exchange for the right to send their mail free of charge. ${ }^{18}$

Reconstructing the extent of the postal network makes it possible to determine the degree of long-distance communication practices at the national level. Having announced that letters could be sent for free, the authorities tried to gauge how the public responded to this measure. Provincial post office managers were charged with implementing the commissioner system. At the same time, they were expected to provide the central authorities with information about their offices, the number of villages served by each office, and the distances between the villages covered by a particular office (with the hope that the same commissioner could be

15. Psurtsev, Razvitie sviazi v SSSR, 69.

16. F. 3527, op. 2, d. 275, 1. 109, RGAE, Moscow.

17. F. 3527, op. 4, d. 42, 1. 407, RGAE, Moscow.

18. F. 3527 , op. 4, d. 11, 1. 15, RGAE, Moscow. 
used to serve them all). Provincial post-office managers were also required to estimate the volume of mail sent and received by each village, the number of commissioners required, and the amount of their salaries. ${ }^{19}$ In short, the government tried to grasp the actual public demand for communication in order to satisfy it.

At the same time that it strove to bring together the postal service and its customers, the regime began to appropriate modern communication technologies for governmental and authoritarian reasons. The project to intensify interpersonal communication was at that time intended to apply only to letters and no other form of exchange. Where long-distance sociability was concerned, space and time did not contract to the same degree as they did in intragovernmental communication. Under War Communism, telephones and telegraphs played a purely functional (rather than relational) role. Their use was limited to emergencies and exceptional events. On April 1, 1920, it was announced that private telegraphic exchanges could be used only to inform loved ones of sickness or death and to search for family members. The same restrictions were applied to private telephone use: a decree from May 6, 1920 made it possible to confiscate private telephones and hand them over to leaders as well as state and party institutions. Private use was limited to free public telephones from which calls could be made only if the lines were not already being used by the authorities. The number of telephone subscribers fell from 232,337 in 1917 to 126,870 in $1921 .^{20}$ In 1922, when the Telephone Association (ob"edinenie telefonnykh predpriiatii) was created as part of the Commissariat for Posts and Telegraphs, its goal was defined as "the satisfaction of the telephone needs of the state-meaning towns, residential areas, and industrial regions." 21 Since priority was given to ensuring that the various structures of the state apparatus could quickly contact one another, the public's needs were not explicitly mentioned.

With the end of the Civil War and the launch of the NEP, private individuals once again had to pay for postal services following an order pronounced on July 28, 1921. The principle of free service that prevailed under War Communism gave way to a profit-based approach under the NEP. This reversal changed prevailing conceptions of long-distance communication practices. Beginning on June 2, 1922, restrictions on private telegraphic and telephone use were lifted. ${ }^{22}$ The return to paid service altered the customer hierarchy. The most privileged groups were clearly identified. An August 1921 circular from the Commissariat for Posts and Telegraphs specified that Red Army soldiers, workers, and employees of both the Soviet state and nationalized companies had the right to send up to two packages a month, weighing a total of no more than one pud $(16.38 \mathrm{~kg})$, of which they would pay only half the cost - the other half being covered by the office or military unit in which the individual was serving. ${ }^{23}$ Shortly thereafter, this was modified by a 
new order, which allowed Red Army soldiers and their families to send one package not exceeding 20 pounds (or $8.19 \mathrm{~kg}$ ) per month free of charge in addition to ordinary letters (weighing less than 15 grams) and postcards. ${ }^{24}$ The right to longdistance communication and mutual assistance was thus defined by social criteria: individuals who were deemed socially useful and classified as "good" were allowed to engage in social relations over a wide geographical area by sending consumer goods. On the other hand, individuals defined as "former people" (byvshie) or "socially alien" and who were associated with the old regime faced discrimination. ${ }^{25}$ The authorities clearly sought to isolate undesirables by restricting their ability to socialize and participate in networks of mutual assistance over long distances. An exception was made for the regions that had suffered the most during the 1921 famine. To facilitate the distribution of food products, the government authorized the free delivery of food packages not exceeding one pud on August 11.26

In the regions that were hit hardest by the famine, such as Volga-Kama, ${ }^{27}$ access to postal services did not necessarily result in an increase in long-distance communication. The authorities' efforts to encourage exchanges between "proletarians of the city, the front, and the village" through cheaper postal rates failed in some areas due to structural and contingent reasons. The social hierarchies promoted by the authorities clashed with the reality of spatial hierarchies, over which they had little control. In a 1922-1923 report, the communications chief for the Volga-Kama region declared that public confidence in the postal service was in a shambles. Explaining its lack of popularity, he pointed to the region's essentially agricultural character, its "low cultural level" (in 1923, 30\% of the region's population between the ages of fourteen and forty was illiterate $\left.{ }^{28}\right)$, and the legacy of the 1921 famine.

\section{Ibid., p. 260.}

25. On the social category of the byvshie and how they became lishency (deprived of civic rights), see Golfo Alexopoulos, Stalin's Outcasts: Aliens, Citizens, and the Soviet State, 1926-1936 (Ithaca: Cornell University Press, 2002); Jean-Paul Depretto, Pour une histoire sociale du régime soviétique, 1918-1936 (Paris: L'Harmattan, 2001), 51-66; Nathalie Moine, "Peut-on être pauvre sans être un prolétaire? La privation de droits civiques dans un quartier de Moscou au tournant des années 1920-1930," Le Mouvement social 196, no. 3 (2001): 89-114; Moine, "Système des passeports, marginaux et marginalisation en URSS, 1932-1953," Communisme 70/71 (2003): 87-108; Sofia Chuikina, Dvorianskaia pamiat': byvshie v sovetskom gorode-Leningrad, 1920-30 gody (Saint Petersburg: EusPB Press, 2006); and Sofia Chuikina and Monique de Saint Martin, "La noblesse russe à l'épreuve de la révolution d'Octobre. Représentations et reconversions," Vingtième siècle. Revue d'histoire 99, no. 3 (2008): 104-28.

26. F. 3527, op. 4, d. 42, 1. 244, RGAE, Moscow.

27. On the 1921 famine and its effects, see Aleksandr Il'iukhov, Zhizn'v èpokhu peremen: material'noe polozhenie gorodskikh shitelei v gody revoliutsii i grazhdanskoi voiny (Moscow: Rosspèn, 2007), 166-83.

28. On the eradication of illiteracy (likbez), see Sumpf, Bolcheviks en campagne; Charles E. Clark, Uprooting Otherness: The Literacy Campaign in NEP-Era Russia (Selinsgrove: Susquehanna University Press, 2000). 
Most of the population engaged in extensive agriculture, aimed solely at consumption, and brought nothing to the market or industry. Lacking reserves and being very poor, they were destined to die due to famine and poor nourishment. ${ }^{29}$

Furthermore, in $1923,68.1 \%$ of post offices in the Volga-Kama regions were, according to the government, "hopelessly in the red." Private correspondence made up 58\% of the mail volume in $1922-1923$ and $69.4 \%$ in $1923-1924$, and personal telegraphic exchanges amounted to $41 \%$ of totals in $1922-1923$ and $67.1 \%$ in $1923-1924 .{ }^{30}$ Moreover, the network itself was rudimentary: in 1923-1924, only $8 \%$ of 10,470 villages received service from the post offices and $5.5 \%$ from the itinerant post. ${ }^{31}$ In the early 1920s, there was very little long-distance communication in the Volga-Kama region, and social networks were extremely restricted. By the mid-1920s, the situation had somewhat improved. In $1925,41.2 \%$ of all localities and $47 \%$ of the population had access to postal services, thanks to the introduction of the system of rural commissioners (sel'skikh pis'monostsev), despite the fact that the initial experience was a failure: commissioners were expected to complete routes of thirty-five kilometers in a single day. Consequently, they did their best to shorten it however they could, notably by avoiding or only occasionally passing through some villages. The following year, the proportions reached $66.3 \%$ and $83.4 \%$ respectively. Village correspondence, however, accounted for only $19.1 \%$ of the region's entire volume. ${ }^{32}$

At the level of the Soviet Union as a whole, the reluctance or impossibility of villages to engage in long-distance communication is even more apparent. In 1924 , despite the fact that $80 \%$ of the population was rural, one letter was received or sent per month for every eight rural inhabitants. ${ }^{33}$ In September 1924, only $8.8 \%$ of all correspondence originated from a village. The rest was sent from cities. ${ }^{34}$ Similarly, city-dwellers used the telegraph far more frequently than villagers. Between 1924 and 1925, 91.6\% of the telegrams (120,480,000 messages) delivered on Soviet territory were sent from cities. ${ }^{35}$ Thus, the countryside, which was bypassed by the flow of exchange, found itself in social and spatial hierarchies that were different from those desired by the regime.

The authorities considered that, by 1926-1927, the process of rebuilding the postal network was complete, since the number of post offices and the length of postal routes finally exceeded those of $1913 .{ }^{36}$ It had taken the Bolsheviks ten years to beat the tsarist regime in this competition upon which their legitimacy rested. At the same time, only $82.7 \%$ of the Soviet Union's population had access to postal services in some 230,548 localities, which represented $51.6 \%$ of all residences.

29. F. 1220, op. 1, d. 4, 11. 2-4, and 47, National Archives of the Republic of Tatarstan, Kazan (Natsional'nyi Arkhiv Respubliki Tatarstan, hereafter "NART").

30. Ibid., 1l. 5, 11, 14, 57, and 61.

31. Ibid., 1. 48.

32. F. 1220 , op. 1, d. 59, 11. 3v-4, NART, Kazan.

33. F. 3527, op. 4, d. 116, 1. 5, RGAE, Moscow.

34. Ibid., 1. 6.

35. Ibid., 1. 6. 


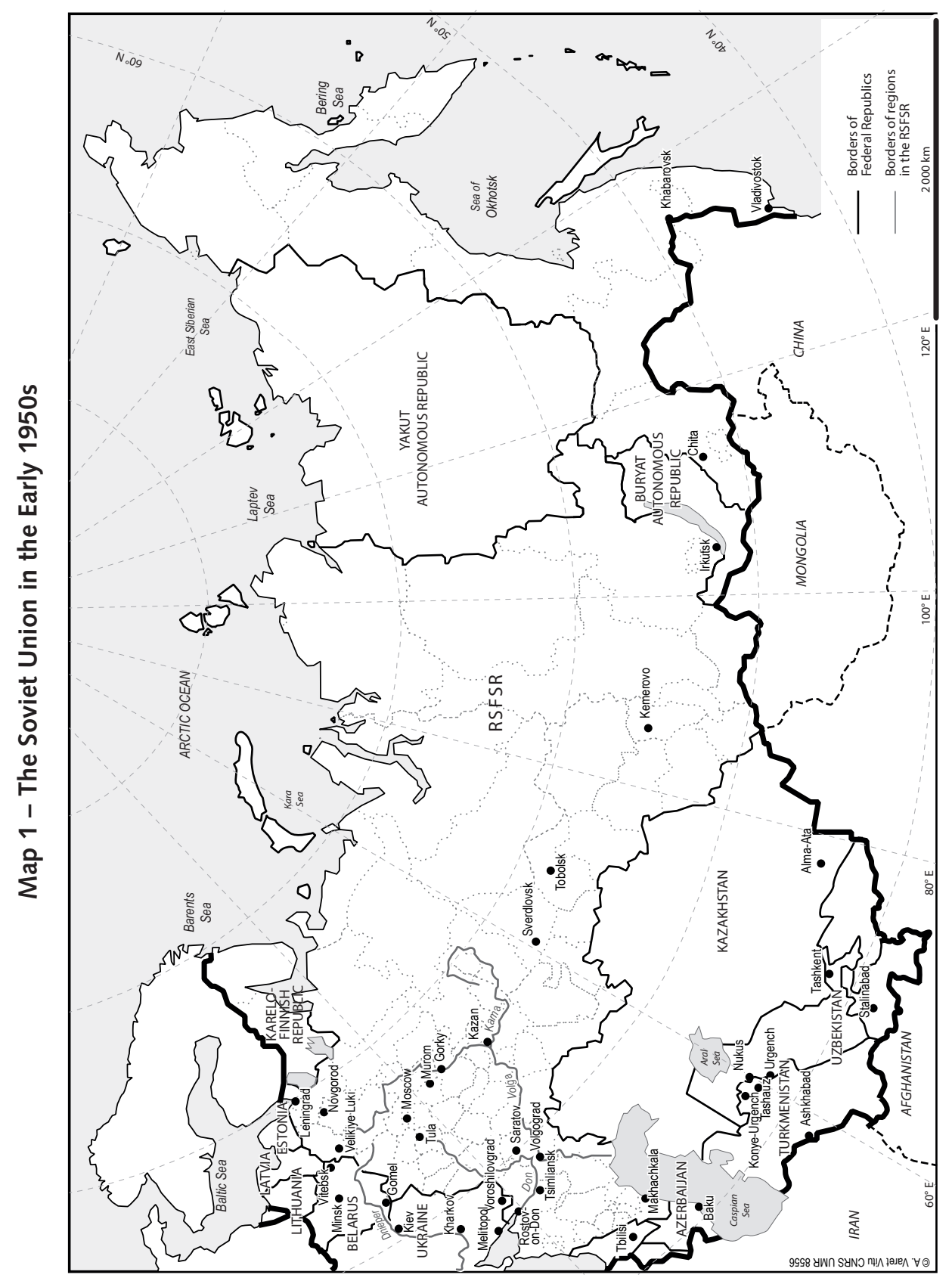


The other half of homes had no access to mail, a fact that is suggestive of the scale of long-distance communication in the USSR during the 1920s. Comparatively speaking, the region or republic that was the most cut off from communication networks was Kazakhstan-only $38.5 \%$ of its population had access to postal services. The percentage for all the central Asian republics taken together was 59.7\%. Almost the same numbers were found in eastern Siberia and the Yakut Autonomous Republic. These inequalities were primarily the result of low population density and poor road quality. ${ }^{37}$ The technical means of communication thus created a hierarchy among the country's various regions. These inequalities resulted from the center's economic and political domination over peripheral territories under the Russian Empire and the Soviet Union, in which governmental communications between the center and the regions trumped the goal of increased interpersonal communication. Disparities were also tied to the authorities' inability to ensure that the network had the same level of density across Soviet territory in addition to weak demand for communication tools in rural areas.

\section{Rising Inequalities during the Period of Forced Socialist Construction}

Once the period of reconstruction was over, the authorities aimed to develop communication networks. Network building plans made no reference-not even implicitly - to the threat that intense interpersonal communications posed to the regime. Plans were elaborated on the basis of economic criteria that took into consideration existing long-distance communication practices. Telecommunications were no longer confined to state use: in 1926, the Leningrad factory Red Dawn signed a technical agreement with the Swedish company Ericsson to begin producing major telephone exchanges. In 1927, to decide how they would be distributed across the territory, the Commissariat opted, on the one hand, to calculate the profits generated by existing telephone lines in order to determine the paths that new lines would follow, ${ }^{38}$ and, on the other hand, to identify the primary postal arteries in order to supplement them with telephone and telegraph lines. ${ }^{39}$ Calculations of potential profit were based on the actual use of communication tools. This way of conceptualizing the network's development tended to reinforce existing social and spatial inequalities. In this technical vision of society and the state, it was presumed that citizens would accept each new technological innovation without reservation, rendering the old ones obsolete. In other words, these calculations were premised on the belief that people who communicated by mail would trade in this "old-fashioned" form of communication for more modern tools such as the telephone and the telegraph. Apprehensions about these tools, which were tied to fears of government control, were not taken into consideration at all.

The social demand for long-distance communication technology did not make such reluctance apparent either: by the 1930s, the demand for communication exceeded the system's ability to respond to and manage it. The growth in demand

37. Ibid., 11. 7-8. 
was tied to the success of the war on illiteracy and to family dispersion, a phenomenon that became increasingly widespread in the late 1920 s and early 1930 s. ${ }^{40}$ The collectivization of agriculture and breakneck industrialization, initiated by Stalin at the height of his power, triggered a mass rural exodus in addition to many deportations. Increasing spatial distances between people made communication increasingly important, even if people stigmatized as kulaks, fleeing collectivization, or facing deportation deliberately let themselves be forgotten and avoided the official postal service by sending letters through couriers. ${ }^{41}$ The 1933 famine may have had the same restrictive effects on long-distance communication practices as those observed during the 1921 famine, but the Commissariat of Communications decided not to collect statistics for 1933-1934, thus covering up the famine's effects on communication. A committee charged with formulating a broad plan for rebuilding the postal system in 1934 used data on mail volume from 1931 and 1932 to draft a plan for $1937 .{ }^{42}$

Among other things, this plan provided for a $195 \%$ increase in small parcels carrying essentially "educational" content: in 1937, authorities in the communications sector believed that the Soviet people would educate themselves through correspondence and that this would result in a rising number of textbooks sent through the mail. ${ }^{43}$ The anticipated $196.4 \%$ increase in package deliveries was justified on the grounds that "village laborers" would buy durable consumer goods (radio sets, sewing machines, watches, etc.) through correspondence because supplies in rural stores were inadequate. According to these predictions, people were expected to use the mail to satisfy their cultural needs instead of receiving the food packages they required because consumer goods were in short supply. In the aftermath of the 1933 famine, the Commissariat maintained that the volume of food packages would decline in 1937 compared to $1932 .^{44}$

On January 1, 1933, the country had 5,257 post offices, 39,356 postal agencies, and 103,131 rural postmen. ${ }^{45}$ The extent of long-distance communication can be qualified by comparing the use of postal services among Western countries (table 1).

Table 1 - Area and Population Served by a Single Post Office in 1932

\begin{tabular}{lccc}
\hline Country & Area $\left(\mathrm{km}^{2}\right)$ & Population & $\begin{array}{c}\text { Population Density } \\
\text { (habitants/km }{ }^{2} \text { ) }\end{array}$ \\
Germany & 11 & 1,536 & 117 \\
England & 17 & 2,002 & 187 \\
France & 31 & 2,337 & 76 \\
United States & 163 & 2,550 & 16 \\
USSR & 476 & 3,704 & 7 \\
\hline \hline
\end{tabular}

Source: f. 3527, op. 4, d. 722, l. 2-3, RGAE, Moscow.

40. While $51 \%$ of the population over the age of ten was illiterate in 1926 , by 1939 , $89.7 \%$ of the RSFSR could read and write: see Clark, Uprooting Otherness, 72-73 and 109. 41. Orlando Figes, The Whisperers: Private Life in Stalin's Russia (New York: Metropolitan Books, 2007).

42. F. 3527, op. 4, d. 722, 1. 8, RGAE, Moscow.

43. Ibid., 1. 10a.

44. Ibid., 1. 11.

45. Ibid., 1. 1. 
The post office shortage was a result of the Soviet Union's low population density. The number of customers for every Soviet post office far exceeded the European and even the American average, revealing the weaknesses of a network that had to cover a territory spanning nearly 22.5 million square kilometers. ${ }^{46}$ At the same time, when considered from the standpoint of population density, access to postal services in the USSR differed very little from the United States. Yet communications practices in the Soviet Union remained much less a part of everyday life than in Europe or the United States (see table 2). This gap can be explained in part by the different economic systems in each society: for instance, mail-order commerce, which had developed in Western countries, was almost nonexistent in the USSR. ${ }^{47}$

\section{Table 2 - Number of Postal Dispatches per Individual in 1932}

\section{Country}

United States

France

England

Germany

USSR
Number of dispatches (letters, postcards, registered letters, parcels and newspapers)

Source:f. 3527, op. 4, d. 722, l. 2, RGAE, Moscow.

In the early thirties, Soviet Union society consisted of social networks that were narrow and closed, but which were gradually opening up (compared to 1924, 0.67 letters were received or sent per rural inhabitant each month ${ }^{48}$ ). A Commissariat of Communications report from 1933 explains this trend by pointing to "an increase in the cultural level of the Union's workers" - in other words, a rise in the literacy rate. It resulted in a considerable volume of mail, which the postal service had to learn to manage. ${ }^{49}$

Awareness of the problem of the geographical location of users was a result of mass use of the postal service. Through their epistolary exchanges, people participated in the organization, shape, and management of urban space. In October 1937, the deputy communications commissar, Vladimir Romanovsky, notified the Soviet's presidium that several Moscow streets bore the same name: there were two streets named Lesnaia, Vorovskogo, Nikolaevskaia, Ogorodnaia, and Tserkovnyi proezd; a street named Leninskikh slobod could be found in three different neighborhoods. Similarly, several buildings on a single street had identical street numbers.

46. Ibid., 1. 4.

47. On the development of mail-order commerce in France, see Philippe Munck, Manufrance, nous accusons (Paris: Éditions de La Vie ouvrière, 1993).

48. F. 3527, op. 4, d. 116, 1. 5 and d. 722, 1. 10a, RGAE, Moscow. See note 33 in this article. 
In order to distribute the mail, the Commissariat requested Moscow authorities to change street names and distribute street numbers properly. ${ }^{50}$

The growing demand for communication resulted in a shortage of new technologies, particularly the telephone. This was the origin of the inequalities made manifest by the way in which access to technology was distributed. In 1926-1927, most urban phone lines were located in major cities: Moscow (48,000 subscribers), Leningrad (41,000), Kharkov and Kiev (5,000 each), Baku (4,600), and Rostov-onDon $(3,600)$. As a whole, these cities represented $51.5 \%$ of the country's telephone subscribers. Spatial hierarchies arising from access to communication remained determined primarily by the network's radial structure: all lines met in the capital, which in practice had privileged access to long-distance communication. Furthermore, Moscow benefited more than other city from new infrastructure: in the 1930s, fifteen telephone exchanges for more than 120,000 phone numbers were installed in the capital. ${ }^{51}$ In central Moscow, telephone density was $5 \%$ (five telephones for every hundred residents), whereas the average density for Soviet cities was $2.2 \%$ (compared to $15.37 \%$ for U.S. cities). ${ }^{52}$ Over the course of twenty-three years of Soviet rule, the number of urban telephones grew by a factor of 3.9, from 265,000 to 1,052,000 subscribers. ${ }^{53}$ Major cities, such as Kiev, Kharkov, Gorky, Moscow, Leningrad, and Tbilisi were most affected by this growth. During this same period-specifically, in May 1941-over 120 district centers (or raion, the smallest administrative unit) did not have a single telephone. ${ }^{54}$

Unequal telephone access was integral to the thinking of communications officials. The projects developed in 1940 to extend the network sought to preserve existing hierarchies: anticipated telephone density would be 25\% for Moscow, 20\% for Leningrad, and $16 \%$ for Kiev, Baku, Tbilisi, Tashkent, Kharkov, Sverdlovsk,

50. F. 3527, op. 4, d. 711, 1. 115, RGAE, Moscow.

51. F. 3527, op. 8, d. 55, 1. 2, RGAE, Moscow.

52. Ibid., 11. 2 and 59. On telephone density in the United States and Europe during the interwar period, see Pascal Griset, Les révolutions de la communication, $X I X^{e}-X X^{e}$ siècle (Paris: Hachette, 1991), 20. He gives the following numbers for the eve of World War II: 15.8 for the United States and 2.7 for the entire European continent (13.6 for Sweden, 5.3 for Germany, 7 for Great Britain, and 3.8 for France). Catherine Bertho and Patrice Carré note that telephone density between French cities was very uneven in 1938: 15 in Paris, 9 in Lille and Bordeaux, and 7 in Nice. "In fact, interwar telephone density follows the map of the French economy rather faithfully: infrastructure is superior in the wealthier and more industrialized north and east, whereas telephones are scarcer in the rural south and west. The only exceptions were several resort towns: Nice, Biarritz, and Saint-Malo-Dinard, for example, were among the first regions to be automated." Catherine Bertho and Patrice A. Carré, "Le téléphone de Clémenceau à Mistinguett, 1914-1939," in Bertho, Histoire des télécommunications, 134.

53. By comparison, the number of telephone subscribers in the United States multiplied by two and a half between 1911 and 1928, whereas it tripled in Europe over the same period. In 1933, the 1929 crisis led to a $13.5 \%$ decline in the number of subscribers in the United States (some 16.7 million). On the eve of World War I, the United States crossed the threshold of twenty million subscribers. Griset, Les révolutions de la communication, 19-20.

54. F. 3527, op. 8, d. 55, 1. 58, RGAE, Moscow. 
and Gorky (cities in which networks were expanded and intensified during the interwar period), and 14\% for Minsk, Yerevan, Alma-Ata, Ashkhabad, Frunze, Rostov-on-Don and other cities of similar size, whereas in cities like Novgorod, Velikiye Luki, Tobolsk, or Murom, six telephones for every hundred inhabitants was deemed sufficient. ${ }^{55}$ The initial contours of the Soviet communication network project were thus already modified by the unequal and hierarchical plans for extending the technological apparatus across the territory. These plans did not seek parity in terms of access to modern technologies, but preserved and even reinforced spatial inequalities. ${ }^{56}$

\section{Discriminatory Communication Services}

Communication tools were seen as rewards offered by the regime. Offering a citizen a telephone line was a way of assigning social status. Conversely, depriving entire communities of access to communication, including the postal service, was a way of conferring disrepute. The Soviet capital was the center of the tensions and symbolic struggles involved in the public policies regarding the allocation of telephone lines, where the tendency of privileged groups to become concentrated in the same neighborhoods was challenged by the logic of city planning, which ignored the configuration of telephone networks. In the collectivized countryside, the "postal labor" required of kolkhoz inhabitants signified their "inferior" social status. In this way, the specificities of public communications services shaped the dynamic of exchange and the social relationships found in cities and the countryside.

\section{The Convergence of Social and Spatial Hierarchies in Urban Areas}

Within urban areas, telephone-line distribution policies reproduced locally the social and spatial hierarchies operating at the national level. The slow growth rate of telephone networks meant that telephones were rare and in high demand. In 1940, Moscow telephone exchanges no longer had any available ports, whereas the unmet demand for telephones rose to between 200,000 and 250,000. ${ }^{57}$ Authorities allocated telephones primarily on the basis of "social utility" and professional status:

55. Ibid., 11. 32 and 58.

56. Spatial and social inequalities were a fundamental characteristic of the Soviet model of development: this can be witnessed in the realm of food supplies and, more broadly, distribution, as well as in the policies of control and repression carried out through the passport system. See: Elena Osokina, Our Daily Bread: Socialist Distribution and the Art of Survival in Stalin's Russia, 1927-1941 (New York: M. E. Sharpe, 2001); Julie Hessler, A Social History of Soviet Trade: Trade Policy, Retail Practices, and Consumption, 1917-1953 (Princeton: Princeton University Press, 2004); and Moine, "Le système des passeports à l'époque stalinienne. De la purge des grandes villes au morcellement du territoire, 
an individual endowed with great responsibility should, according to their reasoning, be reachable at any time, even during periods of rest. When distributing telephone lines, leaders and elites were considered a priority. At the same time, urban planning considerations did not always allow for the allocation of telephones according to social criteria-this obviously adds a layer of complexity to the argument we have made thus far.

Spatial inequalities could be observed at the very heart of the capital. Telephones were initially concentrated in the city center, whereas rebuilding plans called for the development of peripheral neighborhoods and imposed the introduction of telephone lines. The legacy of an earlier building phase meant that in 1940, $55 \%$ of all telephones were located inside the Garden Ring, 30\% between the Garden Ring and the Kamer-Kollezhsky Rampart, and only $15 \%$ further afield. Thus, telephone density varied considerably in Moscow: 5\% in the Boulevard Ring, $3 \%$ in the Garden Ring, 1.4\% inside the Kamer-Kollezhsky Rampart, and only $0.4 \%$ beyond the rampart but inside the ring road. Some districts were less well connected than others: Stalinsky and Sokolnichesky only had 1.7 telephones for every hundred inhabitants (figure 1). ${ }^{58}$ The challenge of finding telephone lines beyond city centers was characteristic of a number of European cities, notably Paris, where the suburbs long remained "poorly connected to the network, the heart of which lay in Paris intra-muros." 59

Following the adoption of the general plan for rebuilding Moscow (19351940), nearly 500 new residential buildings were constructed along Mozhayskoe and Leningradskoe Highways, Gorky Street, Sadovoe Koltso (the Garden Ring), Goncharnaya Street, and the Kotelnicheskaya and Frunzenskaya Embankments. ${ }^{60}$ The apartments were offered to top civil servants, Stakhanovites, and highly ranked military officers. Yet these very comfortable units were not always connected to the telephone network: of the 33,000 apartments built between 1936 and 1940, only 13,000 had telephones. Telecommunications engineers considered this situation scandalous and brought it to the attention of the authorities and urban planning experts. ${ }^{61}$ They demanded that the plan for rebuilding Moscow take the reconfiguration of the telephone network into account. ${ }^{62}$

58. Ibid., 11. 4-5. On the disparities between Moscow neighborhoods in the thirties, see Élisabeth Essaïan, "Kvartal: création d'une nouvelle forme urbaine et d'un nouvel usage d'habitat collectif," in Comment viore ensemble. Prototypes of Idiorrhythmical Conglomerates and Shared Spaces, eds. Paola Viganò and Paola Pellegrini (Venice: Officina edizioni, 2006), 37-55; and Nathalie Moine, "Pouvoir bolchevique et classes populaires : la mesure de privation de droits civiques à Moscou au tournant des années 1930," Cahiers de l'IHTP 35 (1996): 141-59.

59. Bertho, Histoire des télécommunications, 64.

60. On the plan to rebuild Moscow, see Élisabeth Essaïan and Valérie Pozner, "La reconstruction de Moscou, 1935-1940," Le Moniteur architecture 162 (2006): 98-103.

61. F. 3527, op. 8, d. 55, 1l. 3-4, RGAE, Moscow.

62. Ibid., 1. 12. 
Figure 1. Telephone Density by District in Moscow

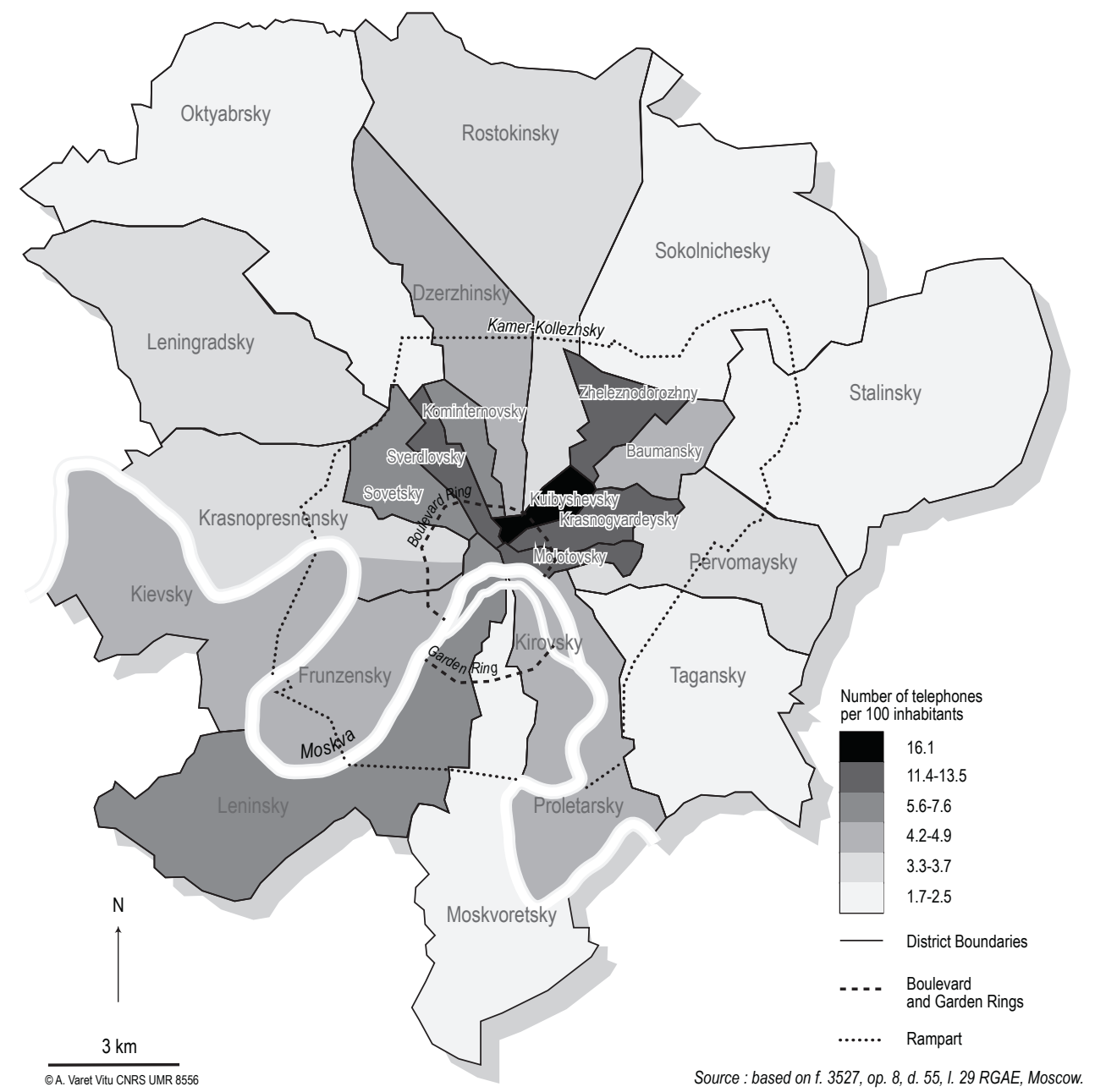

The lack of cooperation between telephone specialists and urban planners confounded assumptions about which of the Soviet capital's neighborhoods were truly reputable. As an actant, the telephone blocked the project of segregating the capital. ${ }^{63}$ While urban planners sought to move prominent neighborhoods away from the center by developing Moscow's belt highways, telephone lines exerted a centripetal force: in 1940, four new buildings on Mozhayskoe Highway had thirteen telephones for 870 apartments, whereas the old building located at 51 Arbat Street had 177 telephones, and 15 Sivtsev Vrazhek Lane had 150. These buildings, located in the city center and housing dozens of communal apartments, had more 
telephones than the new elite homes built along the outskirts, some of which had no telephones at all: building $1 / 8$ of Dmitrovskoe Highway (150 apartments), 92/96 of Leningradskoe Highway (120 apartments), 1/3 Dragomilovskoe Highway, etc. ${ }^{64}$ This situation was denounced by telecommunications engineers, who wanted some consistency between housing and the telephone infrastructure of elite neighborhoods.

Take, for instance, the beautiful buildings of Gorky Street, buildings V and G. They were conceived, built, and inaugurated without being connected to the telephone network. This is why the civil servants who move in are deprived of operational contact with their work and lack elementary comfort. ${ }^{65}$

Engineers invoked the telephone's utilitarian purpose-top civil servants had to be reachable at all times-in order to justify an elitist distribution of resources. But they also described the telephone as a social technology, an inherent feature of material comfort. Furthermore, this vision dovetailed with the use of new technology to spy on Soviet elites: wiretaps, which required costly material as well as human resources, were primarily aimed at people in positions of power. ${ }^{66}$

\section{Communication Discrimination and the Kolkhozes}

Whereas cities evaluated their access to communication tools in terms of telephone density, villages used a different criterion: the availability of postal services. During the 1930s and particularly at the end of World War II, the government's plan to intensify the rural flow of mail was put on the back burner. After collectivization, peasants became de facto second-class citizens. Slogans about "sharing revolutionary ideas" between towns and the countryside now belonged to the past. The state abandoned its commitment to the kolkhozes; even public services like the post office had little to do with them. The postal service's idealistic plan to penetrate the country's most remote corners was abandoned in favor of a more pragmatic approach based on existing communication practices. As social and spatial hierarchies converged, kolkhozes were transformed into enclaves where long-distance communication was limited.

On July 9, 1931 and January 17, 1932, the government issued two orders seeking to improve postal services access for kolkhoz inhabitants and rural areas. It hoped to achieve this goal through two means: first, the network of post offices, which were generally located in the raion seat, would be supplemented by more than 40,000 local agencies and branches; second, kolkhoz directors were charged

64. F. 3527, op. 8, d. 55, 1. 5, RGAE, Moscow.

65. Ibid., 1. 6.

66. See the various documents relating to the wiretapping of elites in the archives of the Russian State Archive of Contemporary History, Moscow (Rossiiskii Gosudarstvennyi Arkhiv Noveishei Istorii): f. 89, per. 18, d. 27, 1. 1; d. 42, 1l. 1-17; d. 49, 1. 1; d. 114, 11. 113; per. 37, d. 44, 11. 1-3; d. 42, ll. 1-5; f. 5, op. 30, d. 412, 11. 18-21. 
with designating inhabitants to distribute the mail to one or two kolkhozes. The collective farms paid these kolkhoz mailmen approximately $0.75 \%$ of a trudoden' (or a workday, the standard remuneration unit) for a full day's work. Kolkhozes provided the horses their mailmen required. ${ }^{67}$ In January 1933, horses were used to deliver mail to $76.6 \%$ of the Soviet population. ${ }^{68}$

Soviet leaders thus replaced the old system of mail commissioners, paid by the postal service, with mailmen remunerated by the kolkhozes. The rationale for this decision was simple: the Commissariat of Communications lacked the resources to offer postal services across the entire territory and fully satisfy demand. ${ }^{69}$ If peasants wished to communicate, it was up to kolkhoz managers to provide the necessary services. Thus, some of the responsibilities once monopolized by the Commissariat were now delegated to institutions of agricultural production. Despite the fact that the order intended to make use of kolkhoz farmers within the raion, in practice, many kolkhoz mailmen and horses had postal routes that cut across these districts. ${ }^{70}$

This new system of mail distribution was disrupted in 1946 by the adoption of a directive issued by the Council of Ministers of the USSR (the new name given the same year to the former Council of People's Commissars) and by the Party's committee "on measures for liquidating violations of the agricultural artel statute in the kolkhozes." As a result of this directive, as well as the fact that local authorities wanted to prohibit the postal service from hiring kolkhoz residents, kolkhozes stopped using their inhabitants to deliver mail. Residents of rural areas were thus obliged to travel by foot to their post offices, which often lay more than twenty kilometers away. To replace the kolkhoz mailmen, the ministry would have had to hire 210,000 new postal workers, representing 759 million rubles in salaries, in addition to purchasing 59,000 horses (which would also have to be fed). Since these expenses seemed prohibitive during the postwar period, Stalin signed a new order confirming the right of each kolkhoz to appoint one of its members to deliver the mail in November 1946. The ministry was nonetheless expected to extend its network and gradually replace kolkhoz horses with automobiles. ${ }^{71}$

On July 1, 1947, the total length of the postal routes along which mail was distributed rose to 669,600 kilometers, of which 534,800 kilometers-the lion's share-was served by transportation originating from kolkhozes. After several inspections by representatives of the Council for Kolkhoz Affairs and local communication

67. F. 3527, op. 4, d. 1576, 1. 3, RGAE, Moscow.

68. F. 3527, op. 4, d. 722, 1. 3, RGAE, Moscow.

69. This thinking is consistent with the basic characteristics of the relationship between the predatory state and the rural world in the USSR. See: Lynne Viola, Peasant Rebels Under Stalin: Collectivization and the Culture of Peasant Resistance (Oxford: Oxford University Press, 1996); Jean Lévesque, “Into the Gray Zone': Sham Peasants and the Limits of the Kolkhoz Order in the Post-War Russian Village," in Late Stalinist Russia: Society Between Reconstruction and Reinvention, ed. Juliane Fürst (London: Routledge, 2006), 103-20. 
officials, the communications minister (commissariats having being renamed "ministries"), Konstantin Sergeichuk determined that it was possible to reduce the number of kolkhoz horses used by the postal service to $15 \%$ and the number of kolkhoz mailmen to $20 \%$. This reduction, which was planned for December 1, 1947, primarily concerned inter-raion routes. The proposal allowed Sergeichuk to request more trucks from the Council of Ministers. ${ }^{72}$ But it can also be seen as a response to actual demand for communication, which was lower than prewar estimates. Such an interpretation of the minister's proposal leads one to conclude that long-distance communication was in decline in the immediate postwar years. This decline can be explained by the loss of life and population movements resulting from evacuations and the shifting frontline. People often had difficulty locating their loved ones. Social bonds that were already stretched thin were ruptured by the war. ${ }^{73}$

\section{Muddled Hierarchies}

In terms of access to communication tools, social and spatial hierarchies were not, however, immutable: they were subject to reconfigurations resulting from technological, political, and short-term factors. The plans to rebuild networks that had been damaged during World War II indicate that there was a clear political desire to return to the radial model and thus to prewar spatial hierarchies. The force of centralization partially confused social hierarchies in peripheral regions, as shortages in communication technology diminished its role as a benchmark of inequality in local communities. The contradictions between, on the one hand, the discourse on the social importance of technological progress, and, on the other, the organization of networks and the distribution of telephone lines led customers to challenge public policies. Malfunctioning service and equipment affected all customers and challenged the very hierarchies that the authorities sought to preserve or reestablish.

\section{The Impact of World War II on Communications}

With World War II, networks grew denser in the eastern regions to which factories and people were evacuated (table 3 ). The western regions that underwent occupation witnessed the destruction of their communications systems. ${ }^{74}$ As the networks were moved from the west to the east during the war, communication policy and planning were disrupted. In 1948, top communications officials realized that goals relating to the flow of mail, money transfers, and the periodical press had not been achieved. The plan's lack of realism underscored the leadership's difficulties in

72. Ibid., 1. 29.

73. On evacuees and their social relations, see Rebecca Manley, To the Tashkent Station: Evacuation and Survival in the Soviet Union at War (Ithaca: Cornell University Press, 2009).

74. F. 3527, op. 7, d. 849, 1. 38, RGAE, Moscow. 
acknowledging the mortality levels resulting from the war and the 1946 famine..$^{75}$ The plan had achieved $94.5 \%$ of its goals relating to letters, $99 \%$ relating to money transfers, and $93.4 \%$ relating to the press. The only realm in which its goals had been exceeded was packages, where it achieved 118.2\%. ${ }^{76}$ These figures clearly show that mail at the time was primarily used to provide mutual assistance: sending consumer products and money transfers rather than letters preserved long-distance social relations. The 1946-1947 famine's impact on patterns of sociability was thus comparable to 1921 .

Table 3 - Distribution of Postal Agencies in the Federal Republics, 1940 and 1948

\begin{tabular}{|c|c|c|c|c|c|c|c|c|c|c|}
\hline \multirow[b]{2}{*}{ Republic } & \multicolumn{5}{|c|}{1940} & \multicolumn{5}{|c|}{1948} \\
\hline & $\begin{array}{c}\text { No. of } \\
\text { agencies }\end{array}$ & $\begin{array}{c}\text { Urban } \\
\text { population } \\
\text { (in } \\
1000 \text { s) } \\
\text { per agency }\end{array}$ & $\begin{array}{c}\text { Rural } \\
\text { population } \\
\text { (in } \\
1000 \mathrm{~s}) \\
\text { per agency }\end{array}$ & $\begin{array}{c}\text { No. } \\
\text { of rural } \\
\text { Soviets } \\
\text { per agency }\end{array}$ & $\begin{array}{l}\text { Area }\left(\mathrm{km}^{2}\right) \\
\text { per agency }\end{array}$ & $\begin{array}{c}\text { No. of } \\
\text { agencies }\end{array}$ & $\begin{array}{c}\text { Of which } \\
\text { in rural } \\
\text { areas }\end{array}$ & $\begin{array}{c}\text { No. } \\
\text { of rural } \\
\text { Soviets }\end{array}$ & $\begin{array}{c}\text { No. } \\
\text { of rural } \\
\text { Soviets } \\
\text { per agency }\end{array}$ & $\begin{array}{c}\text { No. of } \\
\text { agencies } \\
\text { in urban } \\
\text { areas }\end{array}$ \\
\hline Total for the USSR & 51,244 & 8.7 & 2.8 & 1.5 & 430 & 51,486 & 44,332 & 74,685 & 1.7 & 7,154 \\
\hline RSFSR & 32,008 & 9 & 2.5 & 1.4 & 515 & 32,731 & 28,483 & 41,046 & 1.4 & 4,248 \\
\hline Uzbek SSR & 730 & 9 & 8.4 & 2.4 & 560 & 761 & 579 & 1,461 & 2.5 & 182 \\
\hline Kazakh SSR & 2,264 & 7.3 & 2.2 & 1.3 & 1,203 & 2,454 & 2,140 & 2,673 & 1.2 & 314 \\
\hline Kyrgyz SSR & 352 & 6 & 3.8 & 1.7 & 567 & 376 & 312 & 575 & 1.8 & 64 \\
\hline Tajik SSR & 263 & 6.6 & 5.4 & 2.1 & 538 & 280 & 232 & 473 & 2 & 48 \\
\hline Turkmen SSR & 246 & 5 & 5.1 & 2.6 & 1,979 & 282 & 185 & 369 & 2 & 97 \\
\hline Georgian SSR & 648 & 8.8 & 4.5 & 2 & 104 & 714 & 560 & 1,121 & 2 & 154 \\
\hline Azerbaijan SSR & 521 & 8.5 & 5.2 & 2.8 & 163 & 563 & 404 & 1,146 & 2.8 & 159 \\
\hline Armenian SSR & 241 & 9.1 & 4.4 & 3.3 & 121 & 260 & 215 & 713 & 3.3 & 45 \\
\hline Ukrainian SSR & 8,023 & 8.7 & 3.5 & 1.9 & 67 & 7,403 & 6,137 & 16,394 & 2.7 & 1,266 \\
\hline Moldavian SSR & 287 & - & - & 0.8 & 119 & 391 & 353 & 1,236 & 3.5 & 38 \\
\hline Byelorussian SSR & 2,293 & 7 & 2.9 & 1 & 80 & 2,119 & 1,854 & 2,520 & 1.3 & 265 \\
\hline Lithuanian SSR & 713 & - & 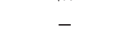 & - & 87 & 780 & 692 & 2,772 & 4 & 88 \\
\hline Latvian SSR & 1,573 & - & - & - & 42 & 1,428 & 1,331 & 1,306 & 1 & 97 \\
\hline Estonian SSR & 690 & - & - & - & 69 & 637 & 585 & 637 & 1 & 52 \\
\hline Karelo-Finnish & & & & & & & & & & \\
\hline SSR & 392 & - & - & 0.6 & 529 & 307 & 270 & 243 & 0.9 & 37 \\
\hline
\end{tabular}

Source: f. 3527, op. 7, d. 849, l. 38, RGAE, Moscow.

Yet these tactics for providing mutual assistance during a famine were numerically smaller than the number of packages mailed during peacetime. While letters sent in 1948 amounted to $72.3 \%$ of the letters sent in 1940 and $91.2 \%$ of letters sent in of 1947 (the decline, among other reasons, is tied to a rate increase for written correspondence), for packages these numbers were respectively $68.7 \%$ and $162.2 \%$, while for money transfers they were $175.2 \%$ and $106 \% .{ }^{77}$ In other words, people were more inclined to help one another with money in 1947 and consumer goods

75. On the 1946-1947 famine in the Soviet Union, which was caused by cereal exports (among other reasons), see Veniamin F. Zima, Golodv SSSR 1946-1947 godov: proiskhozhdenie i posledstviia (Moscow: Institut Rossiiskoi istorii RaN, 1996).

76. F. 3527, op. 7, d. 849, 1. 1, RGAE, Moscow.

77. Ibid., 11. 2-3. 
in 1948. The decline in money transfers between 1947 and 1948 can be explained by the monetary reform, which lowered the public's purchasing power. ${ }^{78}$

This transformation in the demand for long-distance communication occurred at the same time as the opening of new airmail routes, through which the government sought to restore the prewar radial configuration. In 1948, airplanes brought Moscow's letters to new destinations: Vladivostok, Chita, Kemerovo, Molotov, Fergana, Makhachkala, and Voroshilovgrad, which were added to the older destinations first introduced in the twenties (Khabarovsk, Irkutsk, Alma-Ata, Frunze, Stalinabad, Ashkhabad, and Saratov). ${ }^{79}$ Airmail was promoted to customers in advertising campaigns using slogans such as: "Are you familiar with the new postal services?" and "Send mail by plane." 80 The authorities promoted rapid means of communication and encouraged people to cultivate extended social networks. Their reasoning was primarily economic: since the mail circulation plan was not yet complete, the postal service did not generate enough revenue. ${ }^{81}$ Ways to increase profits had to be found.

Since mail followed a radial pattern, it became much easier to develop longdistance ties with the capital's residents than between inhabitants of peripheral regions. The speed of communications was not correlated to geographic proximity. Soviet daily life was shaped by centralization: given that consumer goods were concentrated in the capital's stores, the communication network's radial pattern made it possible to use packages to distribute them across the country.

\section{The Effects of the Radial Communication Pattern}

The effects of wartime destruction, followed by the return of the radial communication pattern, were felt even in the most remote and peripheral of regions. Those who had been mobilized into Stalin's massive projects found themselves the object of de facto discrimination in their access to communication tools, particularly in scarcely populated regions where basic infrastructure was lacking. People working in Kakhovka and Melitopol in Ukraine were privileged to the extent that their worksites were connected to Kiev and other cities by telegraph and telephone extension lines. ${ }^{82}$ On the other hand, in 1951, not a single post office on the VolgaDon canal offered an intercity or intra-village telephone service. Only one post office offered telegraph services, and even these only worked intermittently, with several hour-long interruptions. ${ }^{83}$ This lack of rapid communication tools, which were useful in emergencies, made close social bonds a necessity. Being moved to

78. Ibid., 1. 3. The purpose of the reform was to reduce the sums of money the Soviets had accumulated during World War II. As a result they were divided by three, falling from 43.6 to 14 billion rubles: see Vasily P. Popov, Ekkonomicheskaia politika Sovetskogo gosudarstva. 1946-1953 gg. (Moscow/Tambov: TGTU, 2000).

79. F. 3527, op. 7, d. 849, 1. 9, RGAE, Moscow.

80. Ibid., 11. 29-30.

81. Ibid., 1. 35.

82. F. 3527, op. 4, d. 2050, 1. 34, RGAE, Moscow.

83. Ibid., 1l. 196-197. 
a worksite could readapt people to new social configurations and new forms of solidarity.

The central government seems to have been concerned about the problem of workers' social connections. On May 14, 1951, an order sought to improve communication services on major worksites: the Volga-Don canal, the Stalingrad hydroelectric station, the Tsimlyansk hydraulic center (located some 280 kilometers to the east of Rostov-on-Don), and the Turkmenistan canal. The order's primary motive was to distribute print media in worker communities. ${ }^{84}$ This persistence can be interpreted as a means of preventing the emergence of closed communities, cut off from the rest of the country, inaccessible to political control, and ripe for the development of critical opinion. ${ }^{85}$ The problem of letter distribution (which took eight days from Rostov to Tsimlyansk) was only addressed subsequently. In some of the worksite's villages, it appears that there were no letterboxes at all. Workers were obliged to travel by foot to post offices located ten or more kilometers from their villages. In some post offices, envelopes, stamps, postcards, and paper were lacking, sometimes for periods as long as three months. ${ }^{86}$

At another level, the imperative of organizing communications on major worksites was driven by economic concerns: intercity telephone and telegraph lines were needed to manage the work's progress. Individuals were the tributaries of communication networks created for industrial purposes. In practice, the economic and social use of communication medias was completely intertwined, as evidenced by the committee that examined the state of communication services along the great Turkmen canal in late October 1951. Even the decision to install telephone equipment reflects these dual uses: while some workers did not even have access to the mail, the director of the geological brigade had a telephone in his apartment, which he was expected to use for professional reasons (among others). ${ }^{87}$ Authorities thus sought to apply the Moscow model so as to reproduce social hierarchies in the provinces, even in poorly inhabited areas. In this way, the elitist ideology was in a sense the result of chronic shortages.

The problems that the radial model posed in terms of managing a region's economy or promoting interpersonal communication are obvious. Greater effort was put into facilitating social relations organized along center-periphery axes than into creating connections within particular regions. In 1951, four new post offices were established along the canal. Mail was sent by plane via Tashkent and Ashkhabad, for instance when it was addressed to different localities with no direct connection to one another. In this case, letters took between eighteen and twenty days to reach their destination. ${ }^{88}$

84. Ibid., 11. 24, 33, and 196.

85. On worksites, free workers crossed paths with Gulag prisoners, among whom critical opinions were often widespread: see Nicolas Werth, "Déplacés spéciaux et "colons de travail' dans la société stalinienne," Vingtième siècle. Revue d'histoire 54, no. 2 (1997): 34-50. 86. F. 3527, op. 4, d. 2050, 1l. 196-197, RGAE, Moscow. 
Where technical competence and political will were in short supply, territories found themselves partially or completely excluded from communications coverage. At some points along the canal-Urgench, for example-there were no communication agencies at all. After several months of work, management of the worksite was shifted from Nukus to a new city, Takhiatash, which was twenty kilometers away. A crude shelter with two apartments consisting of eight rooms was set up as a communications office. Eight employees were housed on the premises. In Takhiatash, however, streets were nameless and buildings unnumbered. Since distribution was impossible, all shipments were considered general delivery and were given to their addressees when they passed by the post office. ${ }^{89}$

The situation of the canal builders was comparable to that of the kolkhoz farmers who were asked to provide their own postal service. Telephone lines were lacking between the project's headquarters in Takhiatash and Tashauz, KuniaUrgench, and the western side of the canal in general. In Khodzheili, private mail was not distributed for twenty-seven days and 1,889 packages remained unprocessed for a week. Where public services were relatively undeveloped, local agencies and residents adopted their own tactics: along some routes, the mail was distributed by private individuals who were not even under contract with the postal service. Contracts with kolkhoz mailmen had not been signed either. Sometimes mailmen rode their own donkeys. ${ }^{90}$

Workers seem to have grown accustomed to the limited offerings of communication services: communities tended to withdraw into themselves, neglecting social bonds frayed by increasing mobility. In Nukus, the area for receiving customers was ten square feet. It was poorly lit and short on furniture. Telephone connections with Moscow were difficult and of poor quality. ${ }^{91}$ All this demonstrates the workers' isolation from the rest of the country and the difficulty they faced in trying to preserve long-distance relationships. Meanwhile, a bus made available to the canal project for use as a mobile post office remained idle, since local communications administrators had decided that it was not needed. Even if some orders indicate that the government sought to integrate these workers in communication networks, this concern was low on the central leadership's list of priorities.

\section{An Equal Right to Malfunction}

Unequal access to communication services was not always tolerated. The Commissariat of Communications and the Party Control Committee organized regular inspections to investigate the "post offices' cultural level" and to assess "the extent to which communication services meet the needs of large masses of workers." 92

89. Ibid., 1l. 1-3, 6, 10 and 143-146.

90. Ibid., 1. 148.

91. V. Eristov (chief engineer of the Sredasgidrostroi), "Stalinskii plan pokoreniia Kara-

kumov-v deistvii," Izvestiia, September 12, 1951; F. 3527, op. 4, d. 2050, 11. 1-3, 6, 10, and 143-146, RGAE, Moscow.

92. F. 3527, op. 4, d. 711, 1. 2, RGAE, Moscow. 
These inspections appear to have challenged the spatial hierarchies prevailing in the realm of communications access: they were conducted in several regions and the final report displayed their findings in a comparative chart. Regions in which public services proved the most defective were to be privileged areas of intervention. Customers were also encouraged to denounce malfunctions in the postal, telephone, and telegraph service to the complaints office. By responding to the information this office received, the Commissariat's civil service hoped to make a broad appraisal of the situation and eliminate its most serious defects by partially leveling hierarchies.

During the first eight months of 1936, the central complaints office received 343 complaints regarding telephone communication and 5,592 letters relating to malfunctions in the Soviet postal system, half of which concerned money transfers that had disappeared. $21.5 \%$ of these complaints were unresolved as of September $1 .{ }^{93}$ The system was somewhat resistant to efforts to level hierarchies, which arose from the way in which complaints offices operated. The latter's responses were often very late (with delays of three to four months in Moscow and five months to two years in the provinces) and sloppy, consisting of letters written in bureaucratese. Even when the complaints offices acted with zeal, post offices often refused to respond to their investigations. In 1937, for example, the Azerbaijan communications chief and the director of the Baku central post office spent a whole month ignoring multiple telegrams from the central complaints office relating to the disappearance of a valuable package that had been sent to Baku from Moscow, refusing any involvement in the follow-up to the incident. The same thing occurred at the communications headquarters for eastern Siberia, where the director would not answer several customer complaints, and in Karaganda, Kazakhstan, where the director refused to take material responsibility on behalf of the communication services for the theft of a package's contents. ${ }^{94}$

The service organized to fight the communications system's shortcomings suffered from the same bureaucratic problems. When a customer lodged a complaint with the central complaints office regarding the disappearance of his money transfer in January 1936, he received a negative response on the grounds that there was no proof that the transfer had actually occurred. The file was closed, but it later turned out that the disputed transfer receipts were in the hands of a bureaucrat in the office next door to the official who wrote the negative response. Of the 150 files in the archives that were classified as "closed," forty-seven had not been brought to completion. Customers tried submitting proofs of payment, receipts, and reference numbers: however, in cases handled by several officials, each expected customers to submit exactly the same documents. ${ }^{95}$

As a tool for politically mobilizing customers and involving them in the project of building Socialism, complaints often had little effect. The practice gave people

93. Ibid., 1. 40. 
the impression of participating in politics, while offering the authorities some sense of how public services operated. Yet collecting information did not necessarily result in measures that provided people with the justice they desired. The complaints office did not view customer rights as offering an opportunity to grow as an institution. Instead, it tried to deny problems and lay the blame on customers themselves. In July 1935, someone named Arbuzov approached the complaints office, requesting reimbursement for a package that had disappeared. He had sent it from Omsk to Vagai in the Tyumen region in November 1934. Eight call-backs did not solve the problem. Even communication officials were victims of the postal service's failures. During a trip to Moscow in 1935, a provincial post office director transferred 1,050 rubles from the state account to his own office. When he returned, he discovered that the money had not arrived. No one answered his complaints. Consequently, the amount was withheld from his salary. In October 1935, he approached the central complaints office. He wrote five letters in a row and his post office made seventeen requests- to no avail. At times, the situation was almost absurd: a telegram sent from Tyumen to the head of communications in Omsk did not arrive and was sent back to its point of departure with the following note: "Undelivered, due to lack of recipient." Mailmen in Omsk, in other words, were unable to identify their own central organization. ${ }^{96}$

Confronted with the system's malfunctions, the Soviets thus experienced a kind of equality: the hierarchies that were initially apparent in access to communication tools were leveled not because mistakes were revealed or corrected, but due to the system's own failures. In May 1935, a package sent from the Kalinin region to Omsk was delivered to an individual with the same name as the recipient. The investigation lasted a year and a half, and the file swelled to 140 pages. Some cases took a dramatic turn, like that of someone named Martiushov, who was wired two transfers of 400 and 200 rubles in March 1934. The money was lost and the inquiry dragged on for two years, the recipient dying in the meantime. ${ }^{97}$

As a result of mass use of the postal service and the abuse and disorder that ensued, groups that had benefited from the privilege of preferential postal rates under the NEP lost their advantages under Stalin. When a Red Army soldier complained that a transfer sent from Tambov to Buryatia had been lost, the complaints office refused to investigate because he had no receipt. ${ }^{98}$ The Party Control Commission protested the trend of treating soldiers' complaints just like others. Consequently, it sought to restore some of the old privileges. ${ }^{99}$ According to the investigations, the problems were not confined to peripheral regions, but were also common in Kursk, Voronezh, and even Moscow. ${ }^{100}$

While the postal service did not seek to identify those who were guilty or responsible for such losses until the mid-1930s, contenting themselves at most

96. Ibid., 1. 41.

97. Ibid.

98. Ibid., 1. 42.

99. Ibid., 1. 43.

100. Ibid., 1. 41. 
with reimbursing customers, ${ }^{101}$ the complaints office became particularly important to the authorities in the second half of the decade: information provided by customers served as a pretext for repression. In 1936, the Third Plenary Session of the Party Control Committee adopted a resolution "on the examination of workers' complaints," in which a war was declared on the inefficiency of complaints offices. ${ }^{102}$ It was used to justify repression in the communications sector, which was pursued in the name of equal access to public services. Yet by seeking to eliminate the malfunction that was undermining social and spatial hierarchies, this violent political intervention helped to restore inequality. Between 1936 and 1937, it made it possible to introduce norms for handling complaints that varied in relation to the distance involved (three days for a case affecting one raion and one region, ten days for a krai - the largest administrative unit inside a republic — and forty-five days "for mail sent to the USSR's most distant corners"). ${ }^{103}$ The proclaimed goal of this normalization was to restore workers' trust, since they "confide their savings [and] their letters to their loved ones" to the mail. Consequently, public services had to prove their commitment to mediating social relations and preserving close personal bonds. ${ }^{104}$

The campaign against communications sabotage was also made in the name of denouncing inequalities in telephone access. During the Great Terror in 1937, the paranoid suspicion of "enemy mischief" affected every sector. The directors of the Leningrad telephone service were accused of distributing telephone exchanges unequally across the city: densely populated neighborhoods were allegedly given exchanges intended for a small number of subscribers, while neighborhoods that were already well equipped with telephones benefited from additional exchanges. As a result, it was determined that the plan for developing the Leningrad telephone system was the work of saboteurs. The new administrators were advised to develop an alternative plan that would not reproduce spatial hierarchies. ${ }^{105}$ This kind of accusation was used to replace some administrators. But as Moscow's example suggests, the elitist rationale for distributing telephones was still prevalent among experts in 1940.

On July 27, 1938, the Soviet government called for reinforcement in the fight against sabotage in the communications sector. In the wake of this order, a proposal was made to change the radial pattern so that border zones, ethnic regions, and rural areas could be given better access to communication. In 1939, the new leadership planned to open four hundred new post offices and, in rural areas, 1,350 communication agencies. ${ }^{106}$ Even so, complaints continued to pile up from the 1940s through to the early 1950s (table 4). 
Table 4 - Complaints about Public Communication Services (in Thousands) between 1940 and 1952

\begin{tabular}{lcc}
\hline \hline Year & Total Number of Complaints & Complaints against the Postal Service \\
1940 & 998.8 & 776.7 \\
1945 & 691.1 & 653.4 \\
1946 & 583.8 & 544.4 \\
1947 & 427.9 & 394.8 \\
1948 & 338.2 & 311.8 \\
1949 & 226.9 & 190 \\
1950 & 177.3 & 129.3 \\
1951 & 161.8 & 112.9 \\
1952 & 173 & 119.2 \\
\hline
\end{tabular}

Source: f. 3527, op. 4 d. 2497a, l. 2, RGAE, Moscow.

Unlike during previous periods, customers in early 1953 complained not only about the loss of letters, packages, and money, but also about their mail being opened. ${ }^{107}$ They took the promises made by communication officials in the late 1930s seriously. As a result, they dared to challenge the abolition of telephone privileges in communal apartments by filing a complaint regarding a telephone that had been "illegally" moved from a bedroom to a hallway for collective use. ${ }^{108}$ In this case, the collective telephone worked against the policy of doling out privileges, which the telephone's former owner was attempting to restore. Telephone owners considered their possession as an authentic sign of social distinction, which they had been granted because of their "specific merits." Complaints about the telephone company's refusal to install home telephones followed a similar rationale. ${ }^{109}$ The claimants' perception of their place in the social hierarchy clashed with the view of telephone officials and the availability of technical resources.

This was true of Melamedov, a Muscovite who requested the installation of a telephone in his home in 1949. His request was denied due to limited technical resources. Yet when the network was expanded, the telephone company, having forgotten his request, gave telephones to individuals in his building whose requests had been made later than his. Melamedov made several complaints to telephone services, but was turned down each time. Telephone officials ultimately suggested that he pay 670 rubles so that an additional cable could be extended to his apartment. But Melamedov refused to give up and continued to complain, protesting the fact that he was being charged individually for a cable that could be used to connect several telephones in the building. He was vindicated and only had to pay one-fifth of the total price. ${ }^{110}$ Melamedov decided to challenge the injustices inflicted on him, succeeding despite the technical and human obstacles. Even the argument concerning the telephone network's limited capacity had no effect on him. Significantly, the report on the affair by the central complaints office made no reference

107. F. 3527, op. 4, d. 2497a, 1. 53, RGAE, Moscow.

108. Ibid.

109. Ibid., 1. 54.

110. F. 3527, op. 4, d. 2497a, 1. 55, RGAE, Moscow. 
to Melamedov's socio-professional status, apparently so as not to contradict the principle of distributing telephones according to social criteria.

Yet this emphasis was not always enough to break the institutional logic dictating who was and was not connected to the telephone network. A man named Sokolov harassed telephone officials in Moscow's Miusskii district for seven years, to no avail. In early 1953, he finally wrote a letter to Moscow's central telephone management, which had no better idea than to forward his complaint to district management-in other words, the Miusskii district, which had been ignoring his complaints for the past seven years. ${ }^{111}$ Consequently, in the absence of inter-institutional conflicts, the modus operandi of the bureaucratic pyramid proved to be an efficient device for preserving social asymmetries. The mediating institution, the communications ministry's complaints office, could do little to make up for the technological limitations of the telephone exchanges. Its interventions were limited to a warning sent to the Moscow central telephone management explaining that it was inappropriate to send complaints about a particular authority to that same authority. But this was not the reason a telephone appeared in Sokolov's apartment. The letter he received from the communications ministry's complaints office can be seen as a perfect example of the use of frustration as a power technology. ${ }^{112}$ It expressed disapproval of the institutions that were the target of Sokolov's complaint and gave him reason to hope, while at the same time doing nothing to immediately change the situation. What makes the case interesting is that Sokolov stopped complaining. Institutional interactions resulted in mechanisms that made customer participation in the elimination of what they saw as the system's malfunctions somewhat irrelevant.

In Western historiography, the telephone is often seen as a democratizing tool. ${ }^{113}$ The implicit assumption of this view is that dictatorial and authoritarian regimes refuse to develop telephone systems because they fear they will be used to undermine their power, since-unlike the telegraph, which is associated with hierarchical relations and the transmission of orders-the telephone implies equality between communicators and bilateral exchange rather than unidirectional transmission. Thus, in an article which lacks a precise reference, Henry Boettinger asserts that it was the freedom of expression guaranteed by the telephone that led Stalin to veto Trotsky's plans for a modern Russian telephone system shortly after the revolution. If one is to believe Trotsky's words as relayed by Boettinger, Stalin remarked: "It will unmake our work. No greater instrument for counterrevolution and conspiracy can be imagined." ${ }^{114}$ Yet in Trotsky's writings, no trace of such a conversation is to be found.

111. Ibid.

112. On power technologies, see Cyril Lemieux, Mauvaise presse. Une sociologie compréhensive du travail journalistique et de ses critiques (Paris: Métailié, 2000), 445.

113. See Ithiel de Sola Pool, ed., The Social Impact of the Telephone (Cambridge: MiT Press, 1977); Marie Carpenter, La bataille des télécoms. Vers une France numérique (Paris: Économica, 2011). 
In reality, the improvement of communication tools is closely tied to the history of domination and control. Since the nineteenth century, continental and overseas empires have used technological innovations in the realm of communication to better administer their territories. ${ }^{115}$ With the advent of the telegraph and the telephone, conceptions of technological progress and the efficiency of long-distance governmental technologies became intertwined. Since the beginning of the twentieth century, the use of new communication technology to satisfy social needs has been encouraged: communication builds and organizes the community-indeed, it is the very condition of its existence-and control of the means of communication is what makes society governable. ${ }^{116}$ When an authoritarian regime gets its hands on advanced technology, its desire for control of its territory is taken to extremes, while technological innovation facilitates the arbitrary use of power-and, at worse, repression.

Stalin thus had no reason to oppose the development of the telephone network in the Soviet Union. At a more general level, communication services were often invoked in speeches as proof of Socialism's superiority over Capitalism, since the former guaranteed that all citizens had equal access to communication. Indeed, Soviet leaders took advantage of inequalities in telephone access existing in Capitalist countries, due to the high costs of service, as in the United States, or to technologically undeveloped networks, as in France. Yet the conception of public services that existed in the Western context cannot be easily applied to Stalin's Soviet Union, where values and commitments like the continuity and regularity of service were not respected.

Even if Soviet leaders advertised their desire to bring postal services to the remote countryside and to conquer space and time across their territory through new technology, they found it difficult to determine the actual demand for communication. This was less of a problem in cities, where telephone services kept waiting lists making it possible to know the number of unsatisfied requests for telephone lines. In the countryside, however, officials in the communications sector had fewer tools for measuring demand. The disappointing experiences of the NEP period, when newly-opened post offices in the provinces had few customers and were often in the red, compelled authorities to act with greater caution.

Beginning in 1927, projects for developing the communication network began to depend on the public's actual use of these tools. These practices, in turn, were

115. Jorma Ahvenainen, The Far Eastern Telegraphs: The History of Telegraphic Communications Between the Far East, Europe and America Before the First World War (Helsinki: Suomalainen Tiedeakatemia, 1981); Soli Shahvar, "Tribes and Telegraphs in Lower Iraq: The Muntafiq and the Baghdad-Basrah Telegraph Line of 1863-65," Middle Eastern Studies 39, no. 1 (2003): 89-116; Michael Rubin, "The Telegraph and Frontier Politics: Modernization and the Demarcation of Iran's Borders," Comparative Studies of South Asia, Africa, and the Middle East 18, no. 2 (1998): 59; and Daniel R. Headrick, The Invisible Weapon: Telecommunications and International Politics, 1851-1945 (Oxford: Oxford University Press, 1991).

116. Kai Eriksson, "On Communication in the Modern Age: Taylorism and Beyond," Journal for Cultural Research 11, no. 2 (2007): 125-39. 
based on access to postal, telephone, and telegraph services, which varied from region to region between town and country, center and periphery, and within cities themselves. Analysis of the actual flow of correspondence became a pragmatic consideration in decisions to extend telegraph and telephone lines in places where a high volume of letters were sent. In this way, spatial hierarchies based on access to communication tools, which first emerged at the beginning of the Soviet period, were reinforced under Stalin.

Communication tools imposed a hierarchical arrangement on Soviet territory and society: the telephone was essentially restricted to large cities, while the postal service had difficulty reaching the countryside. It was because of insufficient resources and a fear of deficits that officials imposed the "mail labor" requirement on the kolkhozes. In this way, the state washed its hands of its obligation to satisfy the communication needs of a vast section of this predominantly rural society. When it was implemented, the Soviet project of a communicating society proved deeply unequal and essentially urban in focus.

The war modified this project, shifting networks from the west to the east. But the network's overall pattern remained radial, which facilitated and favored communication between the capital and the provinces. At some of Stalin's vast worksites, infrastructure and public communication services were lacking. In such locations, networks of long-distance sociability had to follow lines and roads that were built to fulfill the economic goals of these projects. While, by removing the contradiction between collectivism and mediated interpersonal communications, the authorities hoped that the postal service would become a conduit for the press and "cultural" goods, the Soviets, who were living in a period of frequent shortages, used it primarily to send food packages to one another.

The practice of allocating telephone lines in cities on the basis of social criteria betrays the elitist outlook of communication officials. From their standpoint, the telephone, which they associated with material comfort and a better-than-average standard of living, belonged in elite housing rather than communal apartments. Yet because the techniques of urban planning did not always make it possible to connect new prominent neighborhoods to telephone exchanges, telephone access did not always reinforce social stratification in practice. Moreover, the tension between collectivism and private communication hardly applied to the telephones found in the hallways of communal apartments, given their quasi-public nature.

Thus the official project of using new, universally accessible communication technology to conquer space and time had little bearing on the practices for distributing this technology to customers. The central complaints office of the Commissariat of Communications was the incarnation of this contradiction between the desire to redress injustice and de facto elitism. This institution, which was created to remedy the communications system's shortcomings and help level hierarchies, was sometimes impotent in the face of chronic malfunction and sometimes a partisan of the elitist outlook. While individuals had some leeway and were able to take advantage of this institutional framework to realize their conception of social justice, long-distance communication remained a dangerous practice in Stalin's Soviet Union, shaped by the country's territorial scale, technological underdevelopment, 
and bureaucratic malfunctioning. This was ultimately the challenge faced in the Khrushchev era: through reforms that divided the country into economic regions and rejected centralization, it changed the organization of communication networks and, by the same token, communication practices. At long last, the telephone arrived in the countryside and peripheral regions were henceforth better integrated into the communication network-tangible evidence that a new era had begun.

Larissa Zakharova Centre d'études des mondes russe, caucasien et centre-européen, EHESS 